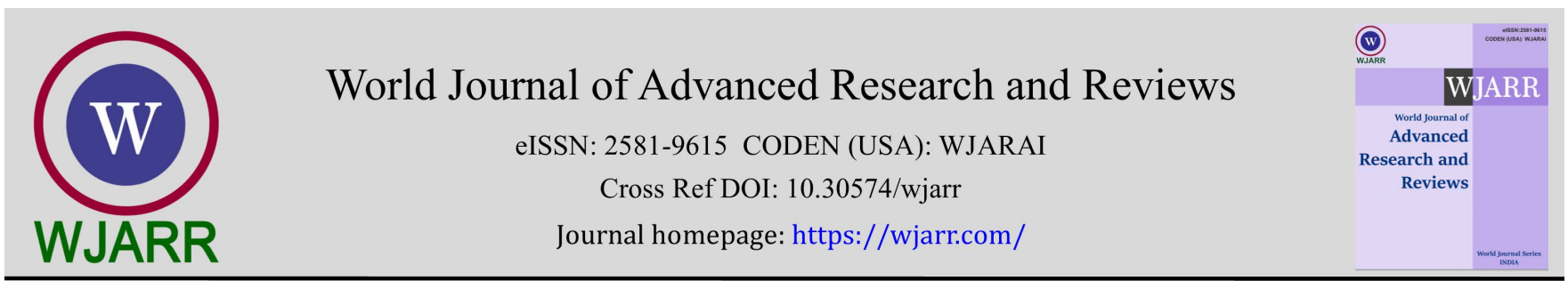

(RESEARCH ARTiClE)

Check for updates

\title{
The prevalence of leukocyte abnormalities among Sudanese patients with sickle cell disease
}

\author{
Tarig Osman Khalafallah Ahmed 1, ${ }^{*}$, Ekhlas Alrasheid Abu Elfadul ${ }^{1}$, Ahmed A. Agab Eldour ${ }^{2}$ and Omer \\ Ibrahim Abdallah Mohammed 3 \\ ${ }^{1}$ Faculty of Medical Laboratory Science, Department of Hematology, University of Kordofan, El-Obeid, Sudan. \\ 2 Faculty of Medicine, Department of Pathology, University of Kordofan, El-Obeid, Sudan. \\ 3 Sharjah Municipality, Department of Public Health Clinic, Sharjah-United Arab Emirates.
}

World Journal of Advanced Research and Reviews, 2021, 09(01), 262-267

Publication history: Received on 15 January 2021; revised on 22 January 2021; accepted on 24 January 2021

Article DOI: https://doi.org/10.30574/wjarr.2021.9.1.0026

\begin{abstract}
Sickle cell disease (SCD) is an inherited blood disorder that affects red blood cells. The study was conducted in Elobied town during the period May 2011 to September 2011. The aim of this study is to detect the abnormalities of leucocytes among sickle cell anemic patients. 40 sickle cell anemic patients; age range between 8 months to 23 years. Blood sample was taken for all patients and the laboratory investigation were performed using automated estimation for: hemoglobin (Hb), Packed cell volume (PCV), red cell count (RBCs), mean cell volume (MCV), mean cell hemoglobin (MCH), mean cell concentration (MCHC), and total white blood cells, comment on blood film using manual methods. The conclusion of this study there is increase in total white blood cells with shift to left in neutrophil precursor in sickle cell patients with complications , the most immature cells are band form, myelocytes and metamyelocytes, and there also lymphocytosis and neutrophilia which has been increases in response to infections.
\end{abstract}

Keywords: Leukocyte abnormalities ; SCD ; Sudanese patients; CBC

\section{Introduction}

Sickle cell disease is a chronic hemolytic disorder that is marked by tendency of hemoglobin molecules within red cells to polymerise and deform the red cell into a sickle (or crescent) shape resulting in characteristic vasoocclusive events and accelerated hemolysis [1,2]. White blood cell (WBC) or leukocyte count is a blood test used to detect a range of blood disorders, evaluate the severity of various underlying diseases, and at times predict the risk of death. High white blood cell (WBC) count is an indicator of sickle cell disease (SCD) severity [3].Bacterial infection area major cause of morbidity and mortality in children with sickle-cell disease. The increased susceptibility of affected children is likely to result from several causes, including impaired splenic function, defects in complement activation, micronutrient deficiencies, and tissue ischemia [4]. Leukocytosis, in the absence of infection, is common in SCD patients and predicts for stroke, acute chest syndrome, and overall mortality. Neutrophils and monocytes have been shown to be activated in these patients [5]. Patients with impaired ability of leukocytes to kill microbes are more prone to infections, which precipitate sickle cell crisis. Reduction of leukocyte count ameliorates SCD. Similarly, targeted blockade or reduced synthesis of specific leukocyte adhesion molecules and their ligands might confer clinical benefit in SCD [6]. The pathogenesis of sickle cell vascular disease is complex and not yet fully understood [5]. The purpose of the current study was to estimate the prevalence of abnormal white blood cells number and types in a sample of Sudanese patients with SCD.

\footnotetext{
* Corresponding author: Tarig Osman Khalafallah Ahmed

Faculty of Medical Laboratory Science, Department of Hematology, University of Kordofan, El-Obeid, Sudan. 


\section{Material and methods}

The current study is Cross-sectional study was conducted in Elobied town during the period May 2011 to September 2011. Ethical clearances were obtained from Kordofan University Ethical committee. Any patient with sickle cell anemia related to this research sign an informed consent. A total of 40 Sudanese sickling patient. Sample collected by simple random sampling data collection and measurement, By special designed questionnaire. About three ml was taken in vacationer tubes in K2 ethylene diamine tetra acetic acid (EDTA) for complete blood counts. Sysmex (hematology analyzer) was used for complete blood counts especially (TWBCs and PLTs) were considered to be measured directly three hydraulic sub systems were sed to determine the hemogram; the WBC channel, the red cell, plat channel and a sprite $\mathrm{Hb}$ channel [7]. Differential count: By manual method and blood film was stained with RALL555 stain (modified Geimsa stain) [8]. Data analysis by using SPSS computer software program version 13.

\section{Results}

The age of study population ranged from 8 month to 24 years within the mean age of 7 years as shown in table (1), of the forty study patients 26 were males and 14 females as shown in figure .About $62.5 \%$ of Sickler patients have normal differential count while $37.5 \%$ have shift to left as shown in table (2). The majority of shift to left sickler (73.3\%) have lymphocytosis as shown in table (3), and (26.7\%) have neutrophilia as shown in table (4). Association of TWBCs and shift to left as shown in the relation between high total white blood cells and shift to left were statistically significant, with $\mathrm{P}$ value (0.0001) as shown in table (5). The majority of patients $(60 \%)$ are complicated with other diseases like bacterial, viral infection, inflammation and thrombosis as shown in figure (3).The most immature cells present in shift to left patients are band form (93.3\%), myelocytes (53.3) and metamyelocytes (26.6\%).

Table 1 showing the distribution of study population by age

\begin{tabular}{|c|c|c|}
\hline Age group & Frequency & Percent \\
\hline Valid less than 1 years & 2 & $5 \%$ \\
\hline 1 & 11 & $27.5 \%$ \\
\hline 4 & 10 & $25 \%$ \\
\hline $7 \_9$ & 5 & $12.5 \%$ \\
\hline $10 \_$12 & 4 & $10 \%$ \\
\hline $13 ـ 15$ & 3 & $7.5 \%$ \\
\hline $16 \_18$ & 3 & $7.5 \%$ \\
\hline $19 \_21$ & 2 & $5 \%$ \\
\hline $22 \_24$ & 0 & $00 \%$ \\
\hline Total & 40 & $100 \%$ \\
\hline
\end{tabular}

Table 2 Distribution by shift to left

\begin{tabular}{|l|l|l|}
\hline & Frequency & Percent \\
\hline Valid normal & 25 & $62.5 \%$ \\
Shift to left & 15 & $37.5 \%$ \\
Total & 40 & $100 . \%$ \\
\hline
\end{tabular}


Table 3 showing association of shift to left and lymphocytosis

\begin{tabular}{|ll|r|r|r|r|}
\multicolumn{7}{|c|}{ lymphocytosis } \\
\hline & & Frequency & Percent & Valid Percent & $\begin{array}{c}\text { Cumulative } \\
\text { Percent }\end{array}$ \\
\hline Valid & yes & 11 & 73.3 & 73.3 & 73.3 \\
& no & 4 & 26.7 & 26.7 & 100.0 \\
& Total & 15 & 100.0 & 100.0 & \\
\hline
\end{tabular}

Table 4 showing association of shift to left and neutrophilia

\section{neutrophilia}

\begin{tabular}{|c|c|c|c|c|c|}
\hline & & Frequency & Percent & Valid Percent & $\begin{array}{c}\text { Cumulative } \\
\text { Percent }\end{array}$ \\
\hline \multirow[t]{3}{*}{ Valid } & yes & 4 & 26.7 & 26.7 & 26.7 \\
\hline & no & 11 & 73.3 & 73.3 & 100.0 \\
\hline & Total & 15 & 100.0 & 100.0 & \\
\hline
\end{tabular}

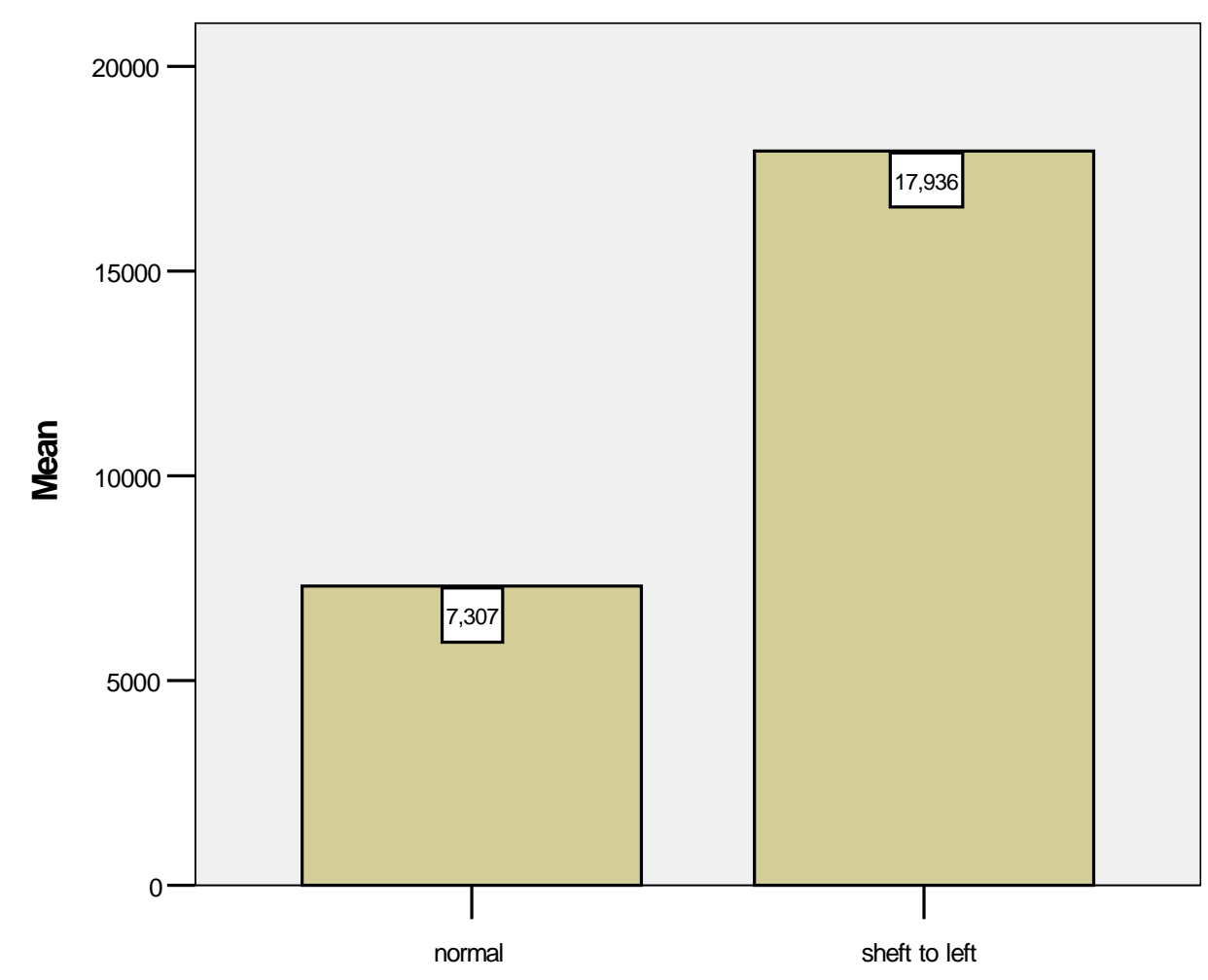

Figure 2 Association of shift to left and TWBCs 
Table 4 The test of normality showed that the total white blood cells in normal and shift to left was normally distributed.

\begin{tabular}{|l|l|l|}
\hline & Kolmogrove-smimov $^{\text {a }}$ & Shaprio-wilk \\
\cline { 2 - 3 } & sig & sig \\
\hline WBCs & & \\
Shift left & .0001 & .0001 \\
Normal & .0001 & .0001 \\
& & \\
\hline
\end{tabular}

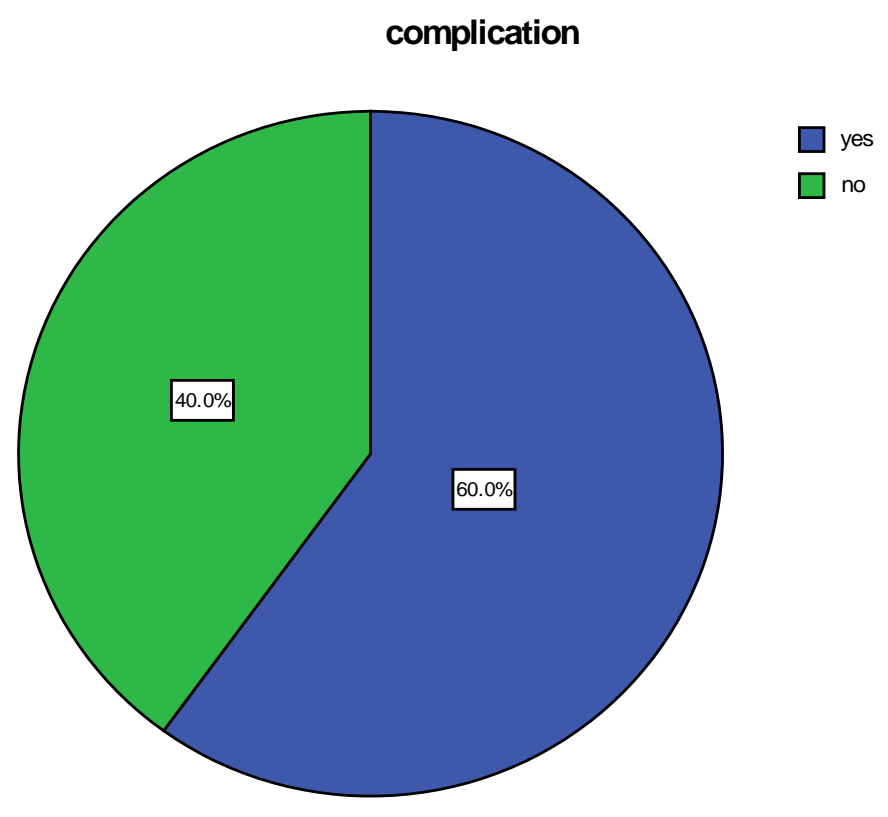

Figure 3 showing that complication may affect on presence of premature WBCs on peripheral blood.

\section{Discussion}

Sickle cell disease (SCD) is an inherited autosomal recessive disorder with presence of Hb S in blood. This disease affects millions of peoples globally which results in serious complications due to vasoocclusive phenomenon and hemolysis. In this study fifteen results from total of 40 results have been showed increase in total white blood cells. This study agrees with study of Okpala (2004) that has been observed leukocytosis in sickle cell anemic patients which precipitates in pathogenesis of vascular occlusion due to increase in leukocytes adherence to endothelium [9]. Lymphocytosis in Sickler patients indicates immunity against infections but we must continually remember that the lymphocytosis is considered normal in children below 2 years (decrease in neutrophil after period of newborn leaving lymphocytes to increase). Also, the results have been showed neutrophilia; it has been found that when there is an increase in neutrophils, when there is acute infection in the body. In this case the numbers of bands are also increased, and this leads to a decrease in the number of other cells in the blood and this is known as neutrophils left shift. Neutrophilia is a risk factor for a sickle crisis [10-13]. The higher the white cell count, the greater the frequency of acute chest syndrome [14] and stroke [15]. Conversely, reduction of the count in patients with sickle cell disease is beneficial. Some studies have been reported in several study [16]. An elevated baseline leukocyte count is associated with an increase risk of early death, and leukocytosis play a significant role in the initiation of vaso-occlusive events [17]. Several limitations can be highlighted in this study. The study recruited SCD patients who attended a single hospital in Elobied city, Sudan. Also, through a questionnaire, all Sickler patients were found to be using supportive therapy which only improve their life example (folic acid and corticosteroid) these drugs may also make total white blood cells and differential abnormal. Also, there 
are many mechanisms in sickle cell disease can change in blood components, blood coagulation during different suckle cell crisis [18].

\section{Conclusion}

The conclusion of this study there is increase in total white blood cells with shift to left in neutrophil precursor in sickle cell patients with complications, the most immature cells are band form, myelocytes and metamyelocytes, and there also lymphocytosis and neutrophilia which has been increases in response to infections.

\section{Compliance with ethical standards}

\section{Acknowledgments}

The authors are warmest thanks to all who participated in this study and especial thank to Elobied Teaching Hospital.

\section{Disclosure of conflict of interest}

All authors have none to declare.

\section{Statement of informed consent}

Ethical clearances were obtained from Kordofan University Ethical committee and Informed consent was obtained from all individual participants included in the study

\section{References}

[1] Eldour AA, Ismail ME, Osman T, Babker A. Red cell alloimmunization in blood transfusion dependent Patients with Sickle Cell Disease in El-Obied city, Sudan. IOSR Journal of Dental and Medical Sciences (IOSR-JDMS). 2015; 14(12):137.

[2] Adewoyin, Ademola Samson. "Management of Sickle Cell Disease: A Review for Physician Education in Nigeria (Sub-SaharanAfrica)." Anemia 2015.

[3] Ahmed, A. E., Ali, Y. Z., Al-Suliman, A. M., Albagshi, J. M., Al Salamah, M., Elsayid, M., Alanazi, W. R., Ahmed, R. A., McClish, D. K., \& Al-Jahdali, H. The prevalence of abnormal leukocyte count, and its predisposing factors, in patients with sickle cell disease in Saudi Arabia. Journal of blood medicine, 2017; 8:185-191. https://doi.org/10.2147/JBM.S148463.

[4] Gladwin MT, Vichinsky E. Pulmonary complications of sickle cell disease. NEngJMed.2008; 359:2254-65.

[5] Wun, Ted. "The role of inflammation and leukocytes in the pathogenesis of sickle cell disease." Hematology 2000; 5, no. 5:403-412.

[6] Agabeldour, Ahmed Abdalla, Tarig Osman Khalafallah, and A. M. AbdAllah. "Hematological changes among Sudanese petroleum workers with a broad range of benzene exposure: Sch." J. App. Med. Sci 3.8D 2015; 30543056.

[7] Babker AM, Di Elnaim E0. Hematological Changes During All trimesters in Normal Pregnancy. Journal of Drug Delivery and Therapeutics. 2020 Mar 15; 10(2):1-4.

[8] Okpala, I.,. The intriguing contribution of white blood cells to sickle cell disease-a red cell disorder. Blood reviews, 2004; 18(1):pp.65-73.

[9] Okpala, I. the intriguing contribution of white blood cells to sickle cell disease-a red cell disorder. Blood Rev. $2004 ; 18: 65-73$.

[10] Litos, M., Sarris, I., Bewley, S., Seed, P., Okpala, I., Oteng-Ntim, E. White blood cell count as a predictor of the severity of sickle cell disease during pregnancy. Eur. J. Obstet. Gynecol. Reprod. Biol. 2007; 133:169-172.

[11] Quinn, C. T., Lee, N. J., Shull, E. P., Ahmad, N., Rogers, Z. R., Buchanan, G. R. Prediction of adverse outcomes in children with sickle cell anemia: a study of the Dallas Newborn Cohort. Blood 2008; 111:544-548.

[12] Miller, S. T., Sleeper, L. A., Pegelow, C. H., Enos, L. E., Wang, W. C.,Weiner, S. J., Wethers, D. L., Smith, J., Kinney, T. R. Prediction of adverse outcomes in children with sickle cell disease. N. Engl. J. Med. 2000; 342:83-89. 
[13] Okpala, I. the intriguing contribution of white blood cells to sickle cell disease-a red cell disorder. Blood Rev. 2004; 18:65-73.

[14] Castro, O., Brambilla, D. J., Thorington, B., Reindorf, C. A., Scott, R. B.,Gillette, P., Vera, J. C., Levy, P. S. The acute chest syndrome in sickle cell disease: incidence and risk factors. The Cooperative Study of Sickle Cell Disease. Blood 1994; 84:643-649.

[15] Ohene-Frempong, K., Weiner, S. J., Sleeper, L. A., Miller, S. T., Embury, S., Moohr, J. W., Wethers, D. L., Pegelow, C. H., Gill, F. M. Cerebrovascular accidents in sickle cell disease: rates and risk factors. Blood 1998; 91:288-294.

[16] Archer, Natasha, Frédéric Galacteros, and Carlo Brugnara. "2015 Clinical trials update in sickle cell anemia." American journal of hematology 2015; 90, no. 10:934-950.

[17] Conran, Nicola, and John D. Belcher. "Inflammation in sickle cell disease." Clinical hemorheology and microcirculation 2018; 68, no. 2-3:263-299.

[18] Mohamed, Elmigdad Abdelgadir, Mamoud Mohamed Elgari, Asaad Mohammed Babker, and Hisham Ali Waggiallah. "Comparative study of hypercoagulability change in steady state and during vaso-occlusive crisis among Sudanese patients living with sickle cell disease." African Health Sciences 2020; 20, no. 1:392-396. 